\title{
RASIO SUKROSA DAN KARAGENAN TERHADAP KARAKTERISTIK FISIKO-KIMIA DAN SENSORI ES KRIM CEMPEDAK (ARTOCARPUS INTEGER)
}

\author{
Tri Rahayuni ${ }^{1}$, Astina ${ }^{1}$ dan Dzul Fadly ${ }^{1 *}$ \\ ${ }^{1}$ Program Studi Ilmu dan Teknologi Pangan, Fakultas Pertanian, Universitas Tanjungpura \\ J1. Prof Hadari Nawawi, Kota Pontianak, Kalimantan Barat, Indonesia \\ *Email : dzul.fadly@faperta.untan.ac.id
}

\section{Article Info \\ Article history: \\ Received July $15^{\text {th }}, 2021$ \\ Revised August 20, 2021 \\ Accepte September $25^{\text {th }}, 2021$}

\section{Keyword:}

Artocarpus Integer; Carrageenan; Ice Cream; Sucrose

\section{Kata Kunci :}

Cempedak; Es Krim; Karagenan; Sukrosa.

\author{
ABSTRACT \\ Background : Ice cream is a frozen food made through freezing and \\ agitation
}

Purpose : This study aimed to determine the effect of sucrose and carrageenan on the physical, chemical, and organoleptic properties of cempedak ice cream.

Method : This study was a Randomized Block Design (RBD) with two factors, Carrageenan $(0.3 \%, 0.4 \%, 0.5 \%)$ and Sucrose $(9 \%, 12 \%$, $15 \%)$.

Results : The best level of carrageenan and sucrose was determined through the effectiveness index test method was $0.5 \%$ carrageenan and $15 \%$ sucrose. The best ice cream products were with chemical characteristics of $1.47 \%$ fat and $15.87 \%$ protein. In addition, there were physical characteristics, in the form of overrun (31.67\%), melting speed (17.87 minutes), and sensory characteristics were ranging from moderate-like on the parameters of taste (3.37), texture (3.43), color (3,31), aroma (3,27), and liking (3,33).

Conclusion : Thus, a right ratio of sucrose and carrageenan produces cempedak ice cream products with appropriate characteristics.

\footnotetext{
ABSTRAK

Latar Belakang : Es krim adalah pangan beku yang melalui proses pembekuan dengan agitasi.

Tujuan : Penelitian ini bertujuan untuk menentukan pengaruh sukrosa dan karagenan pada sifat fisik, kimia, dan organoleptik pada es krim buah cempedak.

Metode : Penelitian ini merupakan Rancangan Acak Kelompok (RAK) dengan dua faktor yaitu Karagenan $(0,3 \%, 0,4 \%, 0,5 \%)$ dan Sukrosa $(9 \%, 12 \%, 15 \%)$.

Hasil : Taraf karagenan dan sukrosa terbaik ditentukan melalui metode uji indeks efektivitas, yaitu karagenan 0,5\% dan sukrosa 15\%. Produk es krim terbaik tersebut memiliki karakteristik kimia, yaitu $1,47 \%$ lemak, dan $15,87 \%$ protein. Selain juga, memiliki karakteristik fisik, berupa overrun $(31,67 \%)$, kecepatan leleh $(17,87$ menit), dan karakteristik sensoris berkisar agak suka hingga suka pada parameter rasa (3,37), tekstur (3,43), warna (3,31), aroma (3,27), dan kesukaan $(3,33)$.
}

Kesimpulan : Demikian, maka rasio tepat sukrosa dan karagenan menghasilkan produk es krim cempedak dengan karakteristik yang sesuai. 


\section{PENDAHULUAN}

Cempedak (Artocarpus intiger) merupakan jenis tanaman tahunan yang berasal dari Indonesia. Produksi buah cempedak di Kalimantan Barat tahun 2018 mencapai 12.027 ton dengan lima urutan kabupaten tertinggi adalah Kubu Raya, Pontianak, Sanggau, Kayong utara, dan Mempawah (BPS, 2019). Buah cempedak menjadi primadona karena rasa dan aroma akibat senyawa aromatic (Krismawati \& Wigati, 2011). Masyarakat mengkonsumsi buah cempedak biasanya dalam keadaan segar atau dibuat cempedak goreng. Namun demikian, buah ini memiliki umur simpan yang singkat karena adanya aktifitas respirasi yang mempengaruhi fisiologis buah sehingga mempercepat pembusukan (Sudjud, 2000).

Pada saat panen raya buah cempedak melimpah dan harga murah. Oleh karna itu perlu upaya diversifikasi pangan untuk memperpanjang umur simpan dalam bentuk olahan pangan menjadi salah satu solusi. Salah satu bentuk diversifikasi pangan adalah dalam bentuk makanan yang digemari masyarakat.

Es krim adalah jenis pangan popular di masyarakat, diproses melalui pembekuan dan agitasi. Produk pangan ini melibatkan produk susu, flavour, pemanis, penstabil, dan pengemulsi. Pembuatan es krim pada umumnya menggunakan bahan penstabil. Wijayanti et al. (2017) menyatakan bahwa penstabil berfungsi mempertahankan tekstur yang lembut, agar tidak cepat meleleh, mempertahankan viskositas, dan penstabil bahan campuran es krim.

Karagenan merupakan salah satu penstabil yang cukup ekonomis. Hal ini dikarenakan harga karagenan instan lebih murah dibandingkan harga bahan penstabil lainnya. Karagenan bisa diperoleh dari rumput laut yang dinilai baik sebagai bahan tambahan pada makanan karena rumput laut merupakan bahan alami (Campbell \& Hotchkiss, 2017).

Pembuatan es krim membutuhkan bahan pemanis untuk meningkatkan cita rasa yang disukai. Sukrosa merupakan pemanis yang umum diaplikasikan pada es krim. Berdasarkan uraian tersebut diatas, pemanfaatan buah cempedak dalam pembuatan es krim dengan penambahan penstabil dan pemanis yang tepat, diharapkan dapat meningkatkan nilai mutu es krim buah cempedak. Penelitian ini bertujuan untuk menentukan karakteristik es krim dengan penambahan sukrosa dan karagenan pada sifat fisik, kimia, dan sensori es krim buah cempedak.

\section{METODE PENELITIAN}

Penelitian ini dilaksanakan di Laboratorium Kimia Pangan dan Desain Pangan, Fakultas Pertanian, Universitas Tanjungpura, selama 6 bulan. Bahan utama dalam penelitian ini adalah Cempedak (Artocarpus intiger) yang diperoleh dari Pontianak, Kalimantan Barat, sukrosa, dan karagenan.

\section{Rancangan Penelitian}

Penelitian ini berdasarkan Rancangan Acak Kelompok (RAK) 2 faktorial, yaitu karagenan dan sukrosa. Kombinasi taraf perlakuan yang digunakan adalah sebagai berikut:

a1b1= Karagenan 0,3\% : Sukrosa 9\%;

a1b2= Karagenan 0,3\%: Sukrosa $12 \%$;

a1b3= Karagenan 0,3\%: Sukrosa 15\%;

a2b1= Karagenan 0,4\% : Sukrosa 9\%;

a2b2= Karagenan $0,4 \%$ : Sukrosa $12 \%$;

a2b3= Karagenan 0,4\%: Sukrosa $15 \%$;

a3b1= Karagenan 0,5\% : Sukrosa 9\%;

a3b2= Karagenan 0,5\%: Sukrosa $12 \%$

a3b3= Karagenan $0,5 \%$ : Sukrosa $15 \%$.

\section{Preparasi Es Krim Cempedak}

Tahap awal adalah buah cempedak masak dibersihkan dan dipisahkan antara daging buah dan bijinya. Daging cempedak yang telah dipisahkan kemudian dihaluskan menggunakan blender dengan penambahan air $1 / 2$ dari berat daging cempedak. 
Pembuatan Es Krim Cempedak Menyiapakan bahan yang digunakan seperti sukrosa (9\%, 12\%, 15\%), 0,1 g garam, karagenan $(0,3 \%, 0,4 \%, 0,5 \%)$, santan $20 \mathrm{ml}$, dan 44,7 $\mathrm{ml}$ air kemudian dimasukkan kedalam panci, masak hingga mendidih sambil diaduk supaya tidak terjadi pemecahan pada santan. (Adonan A) Adonan A dicampurkan dengan 35,2 g daging cempedak yang sudah diblender. Homogenisasi dengan mixer selama 10 menit hingga diperoleh adonan es krim yang homogen. Adonan es krim ditempatkan dalam freezer pada suhu beku selama 4 jam. Pengadukan ini dilakukan 2 kali selama 10 menit setiap 4 jam sekali. Setelah itu masukkan lagi kedalam freezer selama 24 jam pada suhu beku.

\section{Analisi Kimia, Fisik, dan Sensori}

Produk es krim yang telah dipreparasi dianalisis karakteristik kimia, berupa kadar lemak dan protein melalui metode (AOAC, 2012). Kemudian, karakteritik fisik yang ditentukan berupa overrun dan kecepatan leleh. Kemudian, karakteristik sensori diukur melalui uji hedonic oleh 30 panelis tidak terlatih pada parameter rasa, tekstur, warna, aroma, dan kesukaan (Fadly \& Purwayantie, 2019).

\section{Analisis Data}

Hasil Penelitian dianalisis melalui Analysis of Varians (ANOVA) dengan uji BNJ (Beda Nyata Jujur) pada taraf signifikasi 5\% sebagai uji lanjut. Uji kesukaan (hedonik) dianalisis melalui uji Friedman. Penentuan perlakuan terbaik dilakukan melalui uji efektivitas berdasarkan metode indeks efektivitas (De Garmo, dkk., 1984).

\section{HASIL DAN PEMBAHASAN PENELITIAN}

\section{Nilai Overrun}

Overrun didefinisikan sebagai perbedaan volume es krim sebelum dan sesudah proses pembekuan. Nilai ini akan berkontribusi terhadap kepadatan dan tekstur yang merupakan dasar penentu kualitas es krim (Ferraz et al., 2012).

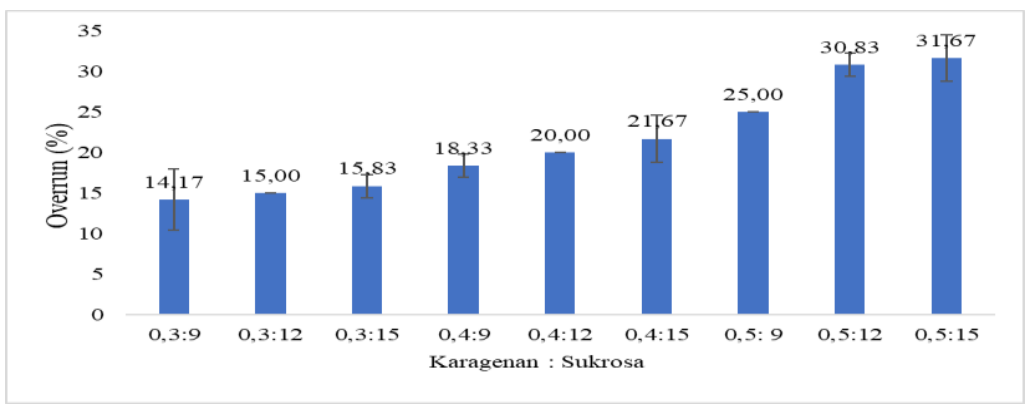

\section{Gambar 1. Nilai Overrun Es Krim Cempedak pada berbagai Rasio Sukrosa dan Karagenan.}

Perlakuan karagenan dan sukrosa berpengaruh nyata terhadap overrun, sedangkan interaksi antara kedua factor tersebut berpengaruh tidak nyata terhadap overrun. Rerata nilai overrun es krim cempedak pada konsentrasi karagenan dan sukrosa disajikan pada Gambar 1.

Nilai overrun es krim cempedak tertinggi terdapat pada perlakuan $0,5 \%$ karagenan dan $15 \%$ sukrosa yaitu $31,67 \%$ dan nilai overrun es krim cempedak terendah terdapat pada perlakuan 0,3\% karagenan dan $9 \%$ sukrosa yaitu $14,17 \%$. Hal ini diduga semakin meningkatnya penambahan karagenan dan sukrosa menyebabkan peningkatan overrun es krim cempedak.

Tabel 1. Uji BNJ Perlakuan Karagenan terhadap Overrun Es Krim Cempedak.

\begin{tabular}{cc}
\hline Karagenan $(\%)$ & Rerata Overrun $(\%)$ \\
\hline 0,3 & $15,00^{\mathrm{a}}$ \\
0,4 & $20,00^{\mathrm{b}}$ \\
0,5 & $29,17^{\mathrm{c}}$ \\
\hline P-value $(\alpha=0.05)$ & 0.021 \\
\hline
\end{tabular}


Hasil uji lanjut BNJ (Tabel 1) perlakuan karagenan 0,3\%, 0,4\% dan 0,5\% berberbeda nyata. Nilai overrun tertinggi terdapat pada penambahan karagenan $0,5 \%$ yaitu $29,17 \%$ dan terendah terdapat pada perlakuan $0,3 \%$ yaitu $15,00 \%$. Hal ini didukung Adi et al. (2014) bahwa penambahan karagenan 0,3\% dan 0,5\% dapat meningkatkan nilai overrun. Pada Tabel 1. menunjukan bahwa semakin banyak penambahan karagenan sebab penstabil mampu mengikat air bebas sehingga udara terperangkap menyebabkan pengembangan adonan lebih tinggi.

Tabel 2. Uji BNJ Perlakuan Sukrosa terhadap Overrun Es Krim Cempedak

\begin{tabular}{cc}
\hline Sukrosa $(\%)$ & Rerata Overrun $(\%)$ \\
\hline 9 & $19,17^{\mathrm{a}}$ \\
12 & $21,94^{\mathrm{b}}$ \\
15 & $23,06^{\mathrm{b}}$ \\
\hline P-value $(\alpha=0.05)$ & 0.021 \\
\hline
\end{tabular}

Hasil Uji Lanjut BNJ (Tabel 2) perlakuan sukrosa 9\% berberbeda nyata dengan perlakuan sukrosa $12 \%$ dan $15 \%$. Nilai overrun tertinggi terdapat pada penambahan sukrosa $15 \mathrm{~g}$ yaitu 23,06\% dan terendah terdapat pada perlakuan $9 \%$ yaitu $19,17 \%$. Overrun cenderung meningkat dengan bertambahnya konsentrasi sukrosa. Gula bersifat menyerap air, sehingga adanya penambahan konsentrasi gula akan meningkatkan jumlah udara yng terperangkap saat proses pembekuan (Hafids et al., 2019). Tingginya udara dalam produk akan mengakibatkan peningkatan overrun (Muse \& Hartel, 2004).

\section{Waktu Leleh}

Waktu leleh didefinisikan sebagai satuan waktu bagi produk es krim untuk secara keseluruhan meleleh.

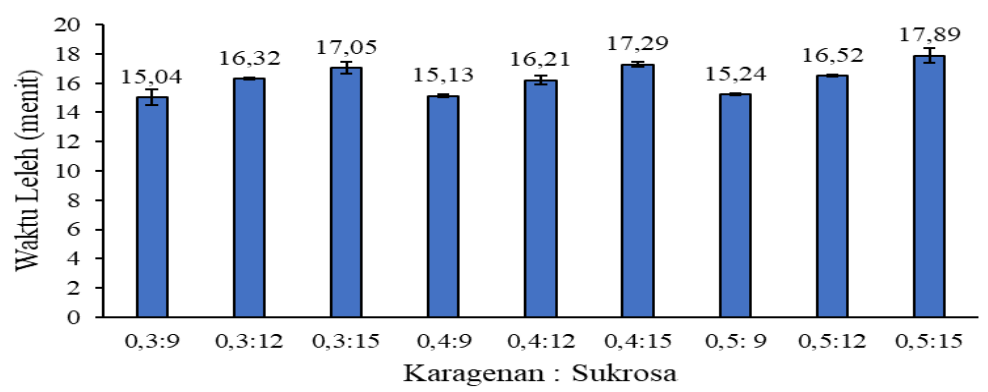

Gambar 2. Waktu Leleh Es krim Cempedak pada berbagai Rasio Sukrosa dan Karagenan.

Perlakuan karagenan dan sukrosa berpengaruh nyata terhadap waktu leleh sehingga dilakukan uji lanjut BNJ 5\%. Interaksi antara sukrosa dan karagenan secara statistic tidak memberikan pengaruh yang tidak nyata terhadap waktu leleh. Dari Gambar.2 diketahui waktu leleh es krim cempedak tercepat pada rasio 0,5 g karagenan: 15 g sukrosa, yaitu 17,89 menit dan waktu leleh es krim cempedak terendah terdapat diperlakuan karagenan 0,3 g dan sukrosa $9 \mathrm{~g}$ yaitu 15,04 menit. Hal ini menunjukkan bahwa setiap penambahan sukrosa dan karagenan mempengaruhi waktu leleh.

Tabel 3. Uji BNJ Perlakuan Karagenan terhadap Waktu Leleh Es Krim Cempedak.

\begin{tabular}{cc}
\hline Karagenan $(\%)$ & Rerata Waktu Leleh $(\%)$ \\
\hline 0,3 & $16,13^{\mathrm{a}}$ \\
0,4 & $16,20^{\mathrm{a}}$ \\
0,5 & $16,55^{\mathrm{b}}$ \\
\hline P-value $(\alpha=0.05)$ & 0.003 \\
\hline
\end{tabular}

Hasil uji lanjut BNJ (Tabel 4) memperlihatkan bahwa 0.5\% karagenan memberikan waktu leleh yang berbeda nyata dengan perlakuan $0,3 \%$ dan $0,4 \%$ karagenan. Nilai waktu leleh tertingi terdapat pada penambahan karagenan $0,5 \%$ yaitu 16,55 menit dan terendah terdapat pada perlakuan $0,3 \mathrm{~g}$ yaitu 16,13 menit. Hal ini didukung hasil penelitian (Violisa et al., 2012), bahwa stabilizer dalam pembuatan es krim ditujukan 
untuk menjaga stabilitas emulsi. Oleh karena itu karagenan sebagai stabilizer pada penelitian ini mampu memperlambat waktu leleh es krim.

Tabel 4. Uji BNJ Perlakuan Sukrosa terhadap Waktu Leleh Es Krim Cempedak.

\begin{tabular}{cc}
\hline Sukrosa $(\%)$ & Rerata Waktu Leleh $(\%)$ \\
\hline 9 & $15,13^{\mathrm{a}}$ \\
12 & $16,34^{\mathrm{b}}$ \\
15 & $17,41^{\mathrm{c}}$ \\
\hline P-value $(\alpha=0.05)$ & 0.003 \\
\hline
\end{tabular}

Hasil uji lanjut BNJ (Tabel 4) perlakuan sukrosa 9\%,12\%, dan 15\% berbeda nyata. Nilai waktu leleh tertinggi terdapat pada penambahan sukrosa $15 \%$ yaitu 17,41 menit dan terendah terdapat pada perlakuan sukrosa 9\% yaitu 15,13 menit. Semakin meningkatnya penambahan sukrosa menyebabkan waktu leleh es krim cempedak semakin lambat akibat adanya peningkatan kekentalan es krim.

\section{Karakteristik Kimia Es Krim Cempedak Kadar Lemak}

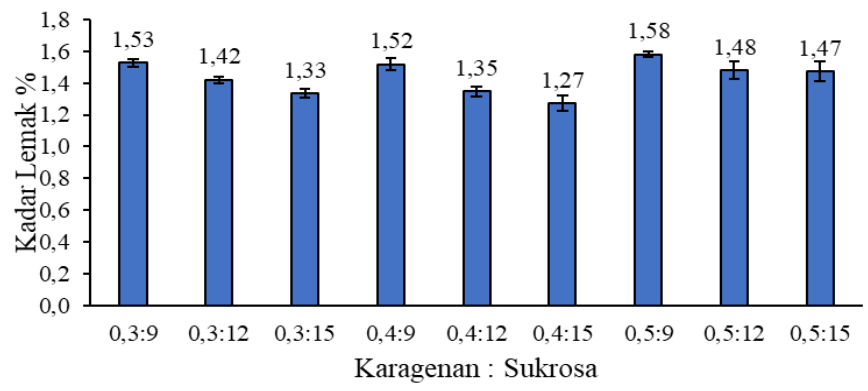

\section{Gambar 3. Kadar Lemak Es krim Cempedak pada berbagai Rasio Sukrosa dan Karagenan}

Penggunaan sukrosa dan karagenan memberikan pengaruh tidak nyata terhadap kadar lemak, begitu pula interaksi keduanya juga memperlihatkan pengaruh tidak nyata pada kadar lemak. Nilai kadar lemak es krim cempedak tertinggi terdapat pada perlakuan penambahan 0,5\% karagenan dan $9 \%$ sukrosa yaitu $1,58 \%$ dan kadar lemak es krim cempedak terendah terdapat pada penambahan 0,4\% karagenan dan sukrosa $15 \%$ yaitu $1,27 \%$. Hal ini diduga karena karagenan hanya sedikit memilki kadar lemak dan sukrosa tidak mengandung lemak yang mampu mempengaruhi kadar lemak. Karagenan diketahui sebagai ekstrak polisakarida rumput laut (Prajapati et al., 2014) sedangkan sukrosa merupakan disakarida yang terbentuk dari dua molekul gula yakni glukosa dan fruktosa (Lunn, 2016).

\section{Kadar Protein}

Dalam es krim, protein merupakan padatan susu non lemak yang berperan dalam pembentukan tekstur dan body produk.

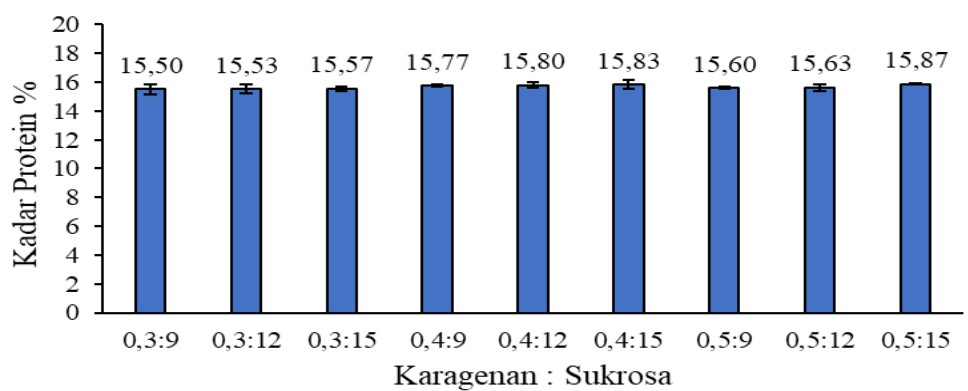

Gambar 4. Kadar Protein Es krim Cempedak pada berbagai Rasio Sukrosa dan Karagenan. 
Perlakuan karagenan dan sukrosa secara tidak nyata mempengaruhi kadar protein produk, demikian pula dengan interaksi keduanya juga tidak berpengaruh nyata terhadap kadar protein. Rerata nilai kadar protein es krim cempedak berbagai konsentrasi karagenan dan sukrosa terdapat pada Gambar 4.

Nilai kadar protein es krim cempedak tertinggi terdapat pada perlakuan penambahan $0,5 \%$ karagenan dan $15 \%$ sukrosa yaitu $15,87 \%$ dan kadar protein es krim cempedak terendah terdapat pada penambahan $0,3 \%$ karagenan dan sukrosa $9 \%$ yaitu $15,50 \%$. Hal ini diduga tidak berpengaruh nyata karena karagenan memiliki kadar protein sedikit yakni 1,9/100 g sedangkan kadar protein sukrosa $0 \mathrm{~g}$ (Raatz et al., 2015).

\section{Karakteristik Sensori Es Krim Cempedak}

Tabel 5. Hasil Uji Hedonik Es Krim Cempedak

\begin{tabular}{cccccc}
\hline $\begin{array}{c}\text { Karagenan (\%) : } \\
\text { Sukrosa (\%) }\end{array}$ & $\begin{array}{c}\text { Mutu } \\
\text { Tekstur }\end{array}$ & $\begin{array}{c}\text { Mutu } \\
\text { Warna }\end{array}$ & $\begin{array}{c}\text { Mutu } \\
\text { Aroma }\end{array}$ & $\begin{array}{c}\text { Mutu } \\
\text { Rasa }\end{array}$ & $\begin{array}{c}\text { Mutu } \\
\text { Kesukaan }\end{array}$ \\
\hline $0,3: 9$ & 3,33 & 2,27 & 3,47 & 4,17 & 3,40 \\
$0,3: 12$ & 3,63 & 2,47 & 3,70 & 3,90 & 3,40 \\
$0,3: 15$ & 3,70 & 2,73 & 3,63 & 3,70 & 3,67 \\
$0,4: 9$ & 3,30 & 2,60 & 3,07 & 3,27 & 3,00 \\
$0,4: 12$ & 3,57 & 2,97 & 3,53 & 3,80 & 3,50 \\
$0,4: 15$ & 4,00 & 3,00 & 3,60 & 3,80 & 3,50 \\
$0,5: 9$ & 3,43 & 2,63 & 3,23 & 3,90 & 3,60 \\
$0,5: 12$ & 3,63 & 2,70 & 3,47 & 3,60 & 3,03 \\
$0,5: 15$ & 3,47 & 3,07 & 3,27 & 4,00 & 3,30 \\
\hline
\end{tabular}

Keterangan : Jika Friedman $>$ Chi $(0,05)=15.507$ maka berpangaruh nyata.

Hasil analisis data pada Tabel 5. menunjukkan menunjukkan rerata nilai terhadap tekstur es krim cempedak yaitu berkisar antara 3,03-3,83 (agak suka sampai suka), rerata nilai terhadap warna berkisar antara 2,90-3,37 (kurang suka sampai suka), rerata nilai terhadap aroma berkisar antara 3,07-3,57 (agak suka sampai suka), rerata nilai terhadap rasa berkisar antara 2,97-3,73 (kurang suka sampai suka) dan rerata nilai terhadap kesukaan berkisar antara 3,00-3,67 (agak suka sampai suka).

\section{Nilai Perlakuan Terbaik Es Krim Cempedak}

Tabel 6. Nilai Perlakuan Terbaik Es krim Cempedak

\begin{tabular}{cc}
\hline Karagenan : Agar-agar & Nilai Perlakuan \\
\hline $0,3: 9$ & 0,39 \\
$0,3: 12$ & 0,36 \\
$0,3: 15$ & 0,61 \\
$0,4: 9$ & 0,24 \\
$0,4: 12$ & 0,51 \\
$0,4: 15$ & 0,57 \\
$0,5: 9$ & 0,58 \\
$0,5: 12$ & 0,49 \\
$0,5: 15$ & 0,74 \\
\hline
\end{tabular}

Pada Tabel 6. menunjukkan hasil analisis pada perlakuan terbaik sebesar 0,74, yaitu penambahan karagenan $0,5 \mathrm{~g}$ dan sukrosa $15 \mathrm{~g}$. Rerata uji sifat fisik: overrun 31,67\% dan kecepatan leleh 17,87 menit, dan sifat kimia : Kadar lemak 1,47\% dan kadar protein 15,87\%. Hasil uji hedonik terbaik yaitu tekstur 3,43 (agak suka sampai suka), warna 3,31 (agak suka sampai suka), aroma 3,27(agak suka sampai suka), rasa 3,37 (agak suka sampai suka), dan kesukaan 3,33 (agak suka sampai suka).

\section{KESIMPULAN}

Demikian, maka rasio tepat sukrosa dan karagenan menghasilkan produk es krim cempedak dengan karakteristik yang sesuai. 
SARAN

Saran penelitian ini yaitu perlu diteliti lebih lanjut kandungan vitamin pada es krim cempedak.

\section{DAFTAR PUSTAKA}

Adi, L. P., Praptiningsih, Y. S., \& Tamtarini. (2014). Pembuatan Es Krim Ekstrak Ubi Jalar Ungu (Ipomea Batatas L.) dengan Variasi Jumlah Penambahan Susu Full Cream dan Karagenan. Jurnal Berkala Ilmiah Pertanian, 1-2.

AOAC. (2012). Official methods of analysis, 19th edition. Association of Official Analytical Chemists (Official methods 968.08, 956.01, and 968.08.).

BPS. (2019). Kalimantan Barat dalam Angka 2019. Badan Pusat Statistik.

Campbell, R., \& Hotchkiss, S. (2017). Carrageenan Industry Market Overview. In A. Q. Hurtado, A. T. Critchley, \& I. C. Neish (Eds.), Tropical Seaweed Farming Trends, Problems and Opportunities: Focus on Kappaphycus and Eucheuma of Commerce (pp. 193-205). Springer International Publishing. https://doi.org/10.1007/978-3-319-63498-2_13

Fadly, D., \& Purwayantie, S. (2019). Karakteristik Sensori dan Kimiawi Non-Meat Burger Patties Berbasis Kearifan Pangan Lokal. Ghidza: Jurnal Gizi Dan Kesehatan, 3(1), 19-24.

Ferraz, J. L., Cruz, A. G., Cadena, R. S., Freitas, M. Q., Pinto, U. M., Carvalho, C. C., Faria, J. A. F., \& Bolini, H. M. A. (2012). Sensory Acceptance and Survival of Probiotic Bacteria in Ice Cream Produced with Different Overrun Levels. Journal of Food Science, 77(1), S24-S28. https://doi.org/10.1111/j.17503841.2011.02508.x

Hafids, S., Rahmi, S. L., \& Chairunisah, A. R. (2019). Study of Low-Fat Ice Cream with The Substitution of Super Red Dragon (Hylocereus costaricensis) Fruit Peel. Indonesian Food Science \& Technology Journal, 3(1), 23-28. https://doi.org/10.22437/ifstj.v3i1.10186

Krismawati, A., \& Wigati, I. (2011). Promosi Dan Usaha Pelestarian di Jawa Timur. Plasma Nutfah Indonesia, 23, 1-3.

Lunn, J. E. (2016). Sucrose Metabolism. In ELS (pp. 1-9). American Cancer Society. https://doi.org/10.1002/9780470015902.a0021259.pub2

Muse, M. R., \& Hartel, R. W. (2004). Ice Cream Structural Elements that Affect Melting Rate and Hardness. Journal of Dairy Science, 87(1), 1-10. https://doi.org/10.3168/jds.S0022-0302(04)73135-5

Prajapati, V. D., Maheriya, P. M., Jani, G. K., \& Solanki, H. K. (2014). RETRACTED: Carrageenan: A natural seaweed polysaccharide and its applications. Carbohydrate Polymers, 105, 97-112. https://doi.org/10.1016/j.carbpol.2014.01.067

Raatz, S. K., Johnson, L. K., \& Picklo, M. J. (2015). Consumption of Honey, Sucrose, and High-Fructose Corn Syrup Produces Similar Metabolic Effects in Glucose-Tolerant and -Intolerant Individuals. The Journal of Nutrition, 145(10), 2265-2272. https://doi.org/10.3945/jn.115.218016

Sudjud, H. R. (2000). Mempelajari Pengaruh Suhu dan Waktu Penggorengan Hampa Terhadap Sifat Fisik dan Organoleptik Keripik Buah Cempedak (Artocarpus integer (Thumb) Merr) [Skripsi]. Institut Pertanian Bogor.

Violisa, A., Nyoto, A., \& Nurjanah, N. (2012). Penggunaan Rumput Laut Sebagai Stabilizer Es Krim Susu Sari Kedelai. Teknologi dan Kejuruan: Jurnal teknologi, Kejuruan dan Pengajarannya, 35(1), Article 1. https://doi.org/10.17977/tk.v35i1.3711

Wijayanti, I. A., Purwadi, P., \& Thohari, I. (2017). Pengaruh Penambahan Tepung Sagu pada Yoghurt terhadap Sifat Fisik Es Krim Yoghurt. Jurnal Ilmu Dan Teknologi Hasil Ternak (JITEK), 11(1), 38-45. 
ISSN : 2656 - 2480 (Online)

ISSN : 2355 - 1364 (Print)

https://doi.org/10.21776/ub.jitek.2016.011.01.4 